\title{
Policy Implementation of Poverty Countermeasure Through Independent Urban 'PNPM' (President Rule Study Number 15 Year 2010 about Acceleration of Poverty Countermeasure in Malang City)
}

\author{
Nurull$^{1 *}$, Bambang Santoso Haryono ${ }^{2}$, Abdul Juli Andi Gani ${ }^{3}$ \\ ${ }^{123}$ Magister of Public Administrative Science, Faculty of Administrative Science Universitas Brawijaya Malang
}

\begin{abstract}
National Program for Community Empowerment (PNPM Mandiri MP) is a government program in accelerating the poverty reduction through community empowerment approach. According to Presidential Regulation No. 15/2010, the National policy strategy of poverty reduction is an attempt conducted by government to tackle poverty. The implementation of community empowerment through PNPM-Urban Mandiri programs involved all stakeholders and policy makers among government, community and others. This study aimed to describe and analyze the process of communication, resources, commitment and bureaucratic structure as well as supporting and hindering factors of PNPMUrban Mandiri implementation. The research method used in this study was qualitative and it was taken in PNPM-Urban Mandiri Kota Malang , East Java Province. The data analysis used was interactive data analyzing models. The result of the study shows that the implementation of PNPM-Urban that the policy of poverty reduction conducted based on the Presidential Regulation No. 15/2010 has still not effectively implemented as well as found some obstacles and problems that caused the objectives has not achieved. They were influenced by communication, resources, commitment, and bureaucratic structures.
\end{abstract}

Keywords: Policy Implementation, Poverty, Empowerment

\section{INTRODUCTION*}

Poverty has to be an acute problem in this country. Several policies and strategies in each regime start from old order, new order and reformation order had been done. Formulation and strategy to resolve poverty endemic had never met the point so the poverty still occurred in this country and it often became politic consumption by the elite. Government policy in poverty countermeasure aims to fulfill people basic needs to make them respected, protected to have more decent life and humane. We cannot deny that poverty problem is locked to each other, not only about one field but also about another field such as access disability of economy, social, culture, politic and participation among people. The principle of poverty problem has not always been about economy, but complex and multidimension. Impartial policy occurred came from politic and economy system which are caused poor people did not have access to economy, politic and democracy resources. The failure of former programs seems that government did not remove the worst forms of poverty but went after high individual income rate by chasing Gross National Product (GNP) growth [2]. Development model which is only expecting growth will caused imbalanced development between modern economy sector and traditional economy sector [3]. Based on statistic data, poverty rate in Indonesia until September 2013 around $11.47 \%$ or around $\mathbf{2 8 . 5 5}$ million people who still life under the poverty line.

In 2010, in order to accelerate poverty countermeasure, President of Republic Indonesia issued public policy, President Rule Number 13 year 2009, about poverty countermeasure coordination and continue with President Rule Number 15 year 2010 about poverty countermeasure acceleration, President instruction Number 1 year 2010 about acceleration of national development priority in 2010 and President Instruction Number 3 year 2010 about equitable development program. Basically, in those policies divided in to 2 major

\footnotetext{
Correspondence address:

Nurul

Email : nurul.affandy77@gmail.com

Address : Jl. Anjasmoro Gg 1A No. 7 Lawang Malang 65213
} 
things which are basic strategy and grouping program of poverty countermeasure.

Ministry of general affair through General Director of Cipta Karya as a part of government body and institution has designed a poverty countermeasure program that is Urban Poverty Countermeasure program (P2KP) which has been held since 1999 as an impact of acceleration regulation of decreasing poverty number. Empowerment has chosen as an approach used in P2KP program implementation to create people and local government independence in poverty countermeasure. In 2007 Urban Poverty Countermeasure program (P2KP), related to its positive result from sectorial program, has been widen to national program which called National Program Independent People Empowerment. The program has become legal protection to all programs with people-empowerment basis.

Urban Poverty Countermeasure Program (P2KP) in Malang city has implemented since 1999 and keep widen their target area. The change from P2KP to PNPM in 2007 has almost reach all target location in east java which are 36 District from 38 District in east java province including Malang city that has 57 village.

Empirical fact stated that poverty countermeasure was not as easy as reverse the hands. Poverty problem is lock to each other fields not just in one field [1]. PNPM MP as the continuity of P2KP understanding poverty as an impact. The method used to overcome poverty need to be refined in order to change attitude and behavior also point of view especially for leaders and policy maker, so they will make policy according to value of humanity, social principal, and sustainable developments pillars [4].

Policy implementation has been seen as a process of administrative and politic act [5]. Implementation of people empowerment program through Urban Independent PNPM involve a lot of policy actor start from local government, central government, people and other. Same comprehension between actors involved in Urban Independent PNPM become standard to guarantee the effective implementation. All implementer must be understand the policy maker preference which its implementation is their responsibility. Communication is a complicated process to potentially digress [6]. Transmission dimension in communication variable require that public policy presented not only to the implementer, but also to a group target [7]. Level of organization structure in urban Independent PNPM start from central, province, district, sub-district and village complicate communication factor among actor involved in policy implementation, it makes the policy harder to implement and reach an expected goal. Different role in each level of Urban Independent PNPM implementer bureaucracy which carried out task as controller, facilitator, and coordination needs a good coordination and disposition pattern among policy actor whether from government (Start from General Affair Government, Local Development Planning Body and General Affair in Province, District, Subdistrict and Village) or Program special corps (Head of Project Management Unit, Development and Environment Planning work unit, Habitation infrastructure Development work unit in District, Responsible person of operational activity in subdistrict and village, non-governmental organization, and Non-governmental group community) to make policy implementation reach its goal. Policy also needs a provided resource, whether it is a budget or other incentive.

Urban Independent PNPM is one of programs to accelerate poverty reduction which used community approach, involving many actors, or stakeholder. As a critical statement said by Edward III that there are four main issues to make effective policy implementation consist of communication, resource, disposition, and bureaucracy system. So, problem formula submitted is : How the implementation of President Rule number 15 year 2010 about acceleration of poverty countermeasure through Urban independent PNPM in Malang city covering aspects of : communication, resource, disposition or attitude and commitment, bureaucracy structure. Each of four variables has sub-variables used as indicator to see effective rate of policy implementation for reaching and succeeding the program as the expectation. This research aims to: 1) describe and analyze communication process, resource, commitment and bureaucracy structure. 2) Describe and analyze supporting and resistor factors of Urban Independent PNPM implementation.

\section{MATERIAL AND METHOD}

This research is qualitative research which describe about implementation of urban independent national program of people empowerment (Urban Independent PNPM) by looking for facts and phenomenon that deeply examined, comprehensive and natural without researcher impartiality [9]. Qualitative research emphasize in meaning, reasoning, definition of 
certain situation. This research means to comprehend phenomenon about what the research subject experienced like behavior, perception, motivation, and act holistically by describing in words and language, in natural special context and by using natural method [10]. Multi stakeholder involved in Urban Independent PNPM with the different role among actor who needs deeply data control and field observation by researcher.

\section{Data Collection}

Start from coordination with government organization/institution took charged in Urban Independent PNPM, researcher mapped the organization/institution or knot information which able to give valid data. Furthermore, researcher start to collect the data through some technics such as: deeply interview key informant who comprehend, involved and have time [11], in this matter are actors who became the part of Urban Independent PNPM organization structure, which are : Local Development Planning Body secretary, Head of Local Coordination Tim of Poverty Countermeasure, Head of People Empowerment Body, General Affair institution, sub-district and village work unit and program companion. Researcher already collected the da through words and acts, additional data like documents and others from the informant, and event [12]. The research data also gained through field observation while documentation in form of information documents regarding to the research. Data analysis has done through condensation data, data presentation and making conclusion [13]. Valid data gained through credibility, detailed description with excellent data and rechecking [14].

\section{RESULT AND DISCUSSION Policy Communication}

It was not easy to drive all stakeholder to involve actively in Urban Independent PNPM. This has happened because comprehension of PNPM $M P$ Vision and orientation was incomplete and only partial in its policy functionary. PNPM MP only understanding as poverty countermeasure project, while during this time the project has been seen as fund sharing from central to local government. This kind of comprehension can be found often in policy functionary and implicated seriously to become resistor in PNPM MP Policy implementation.
Policy implementation process in urban independent PNPM consist of several actors involved start from government in the level of central, province district, sub-district even village. Empowerment approach has become toehold of program implementation in order to give power for poor people [15]. This condition must balance by effective communication in the process of comprehending all policy actors. If there were difference and misunderstanding by policy actor because of ineffective communication, so the policy will be ignored and lessen.

The more lining or implementer actor involved in policy implementation, the bigger resistor and distortion will have happened [16]. This argument is positively correlated if compare with empirical fact in the field of research. The resistor and distortion of the program could be PNPM actor multi stakeholder from central, local to village level and various understanding among implementer [16].

Policy communication build by PNPM MP disseminated, the policy is built through institutional organization forum facilitated by Malang city government to meet various policy actor through City learning community and communication forum among People Nongovernmental organization. PNPM MP in its implementation also spread and give information to stakeholder whether in local government level or people with socialization program. The party who involved in this activity are Women empowerment body and family planning (BKBPM), companion consultant and Local Development Planning Body. Role among the three socialization actors are part of policy transmission in the city level which has different role. The role of Local development planning body are doing coordination and become a mediator, while BKBPM are providing facilities (place and consumption) and companion consultant as an information agent or interviewees. Different role unite in the same responsibility that is delivering information about Urban Independent PNPM.

Socialization became an approaching option in group and it is formal to transmit everything regarding to Urban Independent PNPM in term of program substance, purpose, and step even for implementation and report. The aims are participant gain full information and comprehension about the program and finally will have interest to responsively involve to make policy implement going well as one of condition perfect implementation is perfect communication inside and among organization. Lack of 
information will not give a good comprehension, even the best system cannot guarantee that data, suggestion and order have produced able to understand as the informant expected [17].

Program Socialization will feel barren when people and policy actor did not contributed in PNPM implementation. Substantively, socialization will effect nothing because the actors still not maximum involved in PNPM policy implementation for poverty countermeasure. Socialization happened only for ceremonial but not in comprehension, which lead to real program implementation. Success of policy implementation not only decided by how far policy implementation understand about the policy and able to do it, but also decided by policy actor preference who has strong disposition toward implemented policy.

\section{Policy Implementation Resource}

Human resources capacity become necessity, facilities and infrastructure must be provided but both of them does not mean anything even hard to reach policy purpose without readiness and commitment to implement the policy.

Policy which already formulated cannot be succeed if there is not have resource to implement, whether is human resources or other supporting resources. Success or failure of the implementation can be seen from real ability in keep or operate designed program. Policy implementation ask for providing resource, whether is budget or other incentive. Policy performance will be susceptible if there are insufficient budget to implement the program [5].

Formulated policy cannot reach its purpose if the resource were not provided, whether is human resources or others supporting resources. Implementation success or failure can be seen by its real ability to continue or operate the designed program [5].

Policy implementation ask for providing resource, whether it is the budget or others incentive. Policy implementation susceptible to fail if there is insufficient budget to implement the program. Local capacity, sufficient resource and definite purpose are important matters for policy success [19].

Policy implementation of Urban Independent PNPM in Malang city has shown that implementer resource the activity consist of:

1. Human Resources

Human resources become implementer key in urban independent PNPM divided in 2 categories, which are: Implementer resource in the level of people and in the level of government. Provided resource in this two level quantitatively and based on position has already fit with organization structure and position in existed level. The problem is at the resource in people level, while urban independent PNPM used approach model which placed people as an actor then in urban independent PNPM community has given to one organization that generically called People Empowerment body (BKM). In field implementation policy actor (BKM) admitted that there are some obstacle they faced is about time availability. The occupation member of people empowerment body presented in previous chapter has shown that majority of collective head of BKM are busy with the high work intensity. While implementation in the research field, official of local government hard to describe their multi-job. On one side as official of city government structural, the other side as program implementer.

2. Facilities and Infrastructure Implementation policy has decided by using facilities and tools to reach policy purpose [20]. Even though implementer has already had sufficient staff, comprehend the expectation and gain power, without sufficient facilities, implementation is ineffective [8].

Result of field research has shown that urban independent PNPM implementation facilities given to implementer in the level of people. As a public service organization, they need representative office to serve the people. Urban independent PNPM did not provide something like office, even operational budget of people nongovernmental body prohibited to spend in office. It makes resource implementer at people-level hard to implement the policy. While, at the level of PIC, facilities and inrastructure almost unavailable from Independent PNPM because the existence of PIC in district level double as district secretary, that is why all facilities and infrastructure use anything the district has. Regarding that theor $y$ and condition, urban independent PNPM must concern about resource development whether is human resources or facilities and infrastructure if expecting PNPM MP worked especially for poverty countermeasure in Malang city. 
Implementer Policy Disposition and Commitment

Only ability is insuficient for policy implementer in reaching its goal without readiness and commitment to implement policy. Another factor influence policy effectivity was implementor readiness to carried out that public policy [21]. Attitude and commitment from policy implementer is a must for the implementer to reach their expected goals. There are 3 main elements influence implementer ability and willingness, which are: Kognition is how far the implementer comprehension, implementer guidance and response including acceptance and alignments and responses intencity is implementer character [8].

The result research has shown that implementer comprehension in city goverment level still far away and could be concluded lack of attention that there is PNPM MP in Malang city and the implementer has a job to execute it. Minimum comprehension caused local government and PIC level just did everything they could without sufficient ability to carry out the policy implementation. Administration and ceremonial has become one o rational option for incomprehension implementer to do their job. Acceptance and refusal from policy implementer was decided policy success and failure in public policy implementation [22].

Result reserach of PNPM MP Implementer commitment and attitude in local government level has shown that it come from official government training that makes their incomprehension did not influence their commitment to be unsupportive and avoiding their job. Furthermore, based on the interview result and previous discussion, some of implementer suggested that it is a noble program, a place to share with others and there was no reason to respon this program negatively. Implementer attitude and commitment at this people level in this program deserve to give high appreciation because their willingness concept from 650 people of non-governmental body did their noble job unpaid and with minimum facilities.

This implementer commitment has gained from series awereness and training done by their companion in order to build critical realization that PNPM is from people, by people and for people. According to what happened in Urban independent PNPM in Malang city the implementer tend to have positive attitude about the program. This has indicated that policy will succeed as the first design or decision but still has a challenge, but because of incomprehension, that positive support did not enough to make them implement the policy optimally.

\section{Implementer Bureaucracy Structure}

Policy implementation process is a main part o public policy process becuse without implementing policy is only become concept and nothing. Policy actor role involved in PNPM MP program are to evaluate the whole role. Research result has shown that coordination team o poerty countermeasure did not worked. Practically, PIC itsel did not went well as the expectation. Slowly the role has taken over by indiidual role of local deelopment body official who has a strong commitment towards poverty countermeasure. The role of Local poverty countermeasure coordination team was not corresponding with policy maker expectation. This condition caused role separation among actors and make them lost coordination and interaction. The actors worked partially, so optimalization among the was not filling each other. Family Planning and Women Empowerment institution pointed as technical institution to supervise urban independent PNPM implementation stands alone in supervised and coordinated program implementation.

Ineffective of policy implementation because of lack coordination and cooperation between government institutions [21]. Field research result has shown that coordination among actors still having a problem, just like stated by Development planning body secretary of Malang city, he admitted that Local Poverty Countermeasure Team did not work optimally. PIC was dull and did not working. Incomprehension about role and function also sectorial ego caused they worked differently. Bureaucracy structure position in PNPM MP as policy technical implementer is crucial to support and reach expected target. Ineffective of PNPM MP Policy implementation because of bureaucracy structure weaknesses. Complex dynamics in multi policy actor model, if they were not have cooperation then it will become policy resistor.

Work mechanism formed to manage policy implementation needs Standard Operating Procedure (SOP) which arrange work flow among implementer, moreover if it is involved more than one institution [8]. Responsibility sharing of this actor has been regulated in urban independent PNPM guidance, in special chapter about actor management, but the problem is personally they still uncomprehend fully. This was discovered in 
interview result with the PIC that in fact, PIC lack of PNPM MP Comprehension so in implementing their job was more ceremonial and administrative even though their role is very big. This incomprehension was caused by policy transmission model only through socialization. But, instead of their incomprehension, their commitment is very high. This commitment was not come from program comprehension but more about PIC mental personal as a government official.

Generally, the actor of urban independent of national program people empowerment still were not perform their role according to what was regulated in implementation guidance of urban independent PNPM year 2012. Coordination among implementer actor must be increased in order to unite perception, filling each other and sharing interaction of their role. Implementer actor involvement in a policy has a different interest. But good cooperation and coordination, also similar point of view about the expected aims, implementation process would have went more effective and efficient. Weak of coordination and synergy among policy actor confirmed that policy implementation was not going well, lack of personal comprehension about the program crystalized in each institutions while it should be locomotive in program policy implementation.

Actor in a policy will have a bigger opportunity to reach their goal if they can cooperate with another actor who has similar vision/goal. Not optimum coordination, communication and synergy among actor contributed in the program become obstacle in policy implementation, it make it worse with the actor who did not focus because they have a double job. That was implicated in policy implementation optimization. In fact, for effective policy implementation, coordination, communication and collaboration, must worked well.

\section{Supporting and Resisting Factor of PNPM MP Implementation}

Policy which has recommended to implement, will have many influenced variable, whether is individual or group or institution. Policy implementation will succeed if supported by factors which are make policy went well according to the expectation. The factors consist of supporting and resisting factor. In its implementation supporting factor of PNPM MP are: first, budget support from district government in form of local budget allocation for group business and providing companion operational. Second, actor behavior in the level of bureaucracy and people be a part of supporting factor which influence policy success. Third, volunteer existence. While resistor factors are lac of comprehension and official mutation in bureaucracy level, Complication of PNPM MP implementation and regeneration people policy actor also domination of companion role.

\section{CONCLUSION}

Urban independent PNPM implementation is poverty countermeasure policy according to president rule number 15 year 2010, still ineffective from the expectation. In other word, urban independent PNPM implementation in Malang city for 10 years still ineffective influenced by some factors, which are:

1. Communication process, policy transmission has been done by independent PNPM trough socialization activity towards policy actor especially actor in bureaucracy level was not optimal but more ceremonial and formal. This was caused policy actor in bureaucracy level still uncomprehend fully about policy concept and policy operational. While policy communication to people schemed trough special training for people was effective enough so actor comprehension in actor level better than in bureaucracy level.

2. Resource factor, human resources become key implementer in urban independent PNPM divided in 2 categories which are: implementer resources in people level and government level. Resource availability in those 2 level resources quantitatively and according to occupation has already fulfilled based on existence organization structure and position. Urban independent PNPM using approach model which placed people as an actor. Obstacle that they faced was time availability, while in the government level was difficulty to differ their job as a structural official in government and program implementer of PNPM MP.

3. Disposition/commitment factor. Policy implementer comprehension in government level still far from understand. Lack of policy actor comprehension effected to response implementer just did what they need to do without the ability to implement the policy and power. Administration and ceremony has to be a rational option of their incomprehension as policy implementer.

4. Bureaucracy structural factor, local poverty countermeasure team in charged to elaborate all poverty countermeasure actor 
including PNPM MP still did not work because this team is less active so that role has taken over by individual official in local development body which has strong commitment in poverty countermeasure. This condition caused incoordination and no interaction among policy actor. Bureaucracy and coordination structure from top to the bottom or otherwise is dulled, double role is often happened between local government official and program structure official.

Supporting and resisting factors of PNPM MP Budget support from city government by allocating local budget for general business and providing companion operational;Actor commitment in people and bureaucracy level, third, the existence of community volunteer. While resisting factor of PNPM MP policy implementation are lac of comprehension and official mutation in bureaucracy level, complicated procedure of PNPM MP implementation and regeneration policy actor in people level and domination companion role.

\section{SUGGESTION}

a) Policy transmission has already used must be improve with special technical training pattern in bureaucracy level and socialization process focused on improving policy actor comprehension

b) Policy implementer in bureaucracy level should not be official who has position in structural but certain official to implement the program.

c) Malang city government give an appreciation to volunteer actor in people level

d) Local poverty countermeasure team design coordination mechanism, supervised and reported by policy actor.

e) Malang city government must soon prepare sustainable concept and program replication.

\section{REFERENCES}

[1]. Sumodiningrat, Gunawan. 1996. Memberdayakan Masyarakat: Kumpulan Makalah mengenai Inpres Desa Tertinggal, Penakencana Nusadwipa, Jakarta.

[2]. Mahbub UI Hag 1983, Tirai Kemiskinan :tantangan-tantangan untuk Dunia ketiga, Yayasan Obor Indonesia, Jakarta.

[3]. Sutrisno, L., 1993. Beberapa faktor dalam dan luar negeri yang berpengaruh pada kelestarian pembangunan di Indonesia. P3PK [= Pusat Penelitian Pembangunan Pedesaan dan Kawasan]: PPK UGM [= Pusat Penelitian Kependudukan, Universitas Gadjah Mada.

[4]. Pedoman Umum PNPM Mandiri Perkotaan 2008, Bersama Membangun Kemandirian, Direktorat Jenderal Perumahan dan Permukiman, Departemen Permukiman dan Prasarana Wilaya

[5]. Abdul Wahab, Solichin. 2008a. Analisis Kebijaksanaan dari Formulasi ke Implementasi Kebijaksanaan Negara, Bumi Aksara, Jakarta

[6]. Wibawa, Samodra 1994. Kebijakan Publik Proses dan Analisis. Intermedia.Jakarta

[7]. Widodo, Joko 2001, Good Governance Telaah Dari Dimensi Akuntabilitas, Kontrol Birokrasi Pada Era Desentralisasi Dan Otonomi Daerah, Surabaya : Insan Cendekia

[8]. Triana Wahyuni, Rochyati 2011. Implementasi dan Evaluasi Kebjakan publik, PT. Revka Petra Media, Surabaya

[9]. Sarwono, Jenathan. (2011). Mixed Metods : Cara Menggabung Riset Kuantitatif dan Kualitatif secara Benar. Elex Media Komputindo. Jakarta

[10]. Alwasiah, chaeder A. (2002). Pokoknya Kualitatif : Dasar-dasar Merancanng dan Melakukan Penelitian Kualitatif. Pustaka Jaya. Jakarta

[11]. Moleong, Lexy J. 2007. Metodologi Penelitian Kualitatif. Bandung, PT. Remaja Rosdakarya.

[12]. Sugiyono. 2011. Metode Penelitian Kualitatif dan Kuantitatif. Bandung : Alfabeta

[13]. Matthew B miles, A. Michael Huberman, Johny Saldana. 2014. Qualitative Data Analysis, Arizona State University United States Of America.

[14]. Lincoln, Yvone \& Egon G. Guba. 1985. Naturalistic Inquiry, SAGE Publication,

[15]. Fahrudin, Adi. 2004. Pemberdayaan, Partisipasi dan Penguatan Kapasitas Masyarakat, Humaniora, Bandung

[16]. Lucie Cerna 2013. The Nature of Policy Change and Implementation: A Review of Different Theoretical Approaches, Organization for economic co operation and development.

[17]. Tachjan, H. 2006. Implementasi Kebijakan Publik, Bandung: AIPI Bandung-Puslit, KP2W Lemlit UNPAD.

[18]. Nugroho, Riant. D 2012. Kebijakan Publik, Formulasi, Implementasi dan Evaluasi. Jakarta. Elex Media Computindo. 
[19]. Nugroho, Riant. D. 2012. Kebijakan Publik, Formulasi, Implementasi dan Evaluasi. Jakarta, Elex Media Computindo.

[20]. Agustino, Leo. 2006. Politik dan Kebijakan Publik. AIPI Bandung

[21]. Subarsono, AG. 2009. Analisis Kebijakan Publik, Konsep, Teori dan Aplikasi, Pustaka Pelajar, Yogyakarta

[22]. Winarno, Budi. 2005. Teori \& Proses ebijakan Publik. Yogyakarta: Media Pressindo.

[23]. Wahab, S.A., 2012. Analisis kebijakan: dari formulasi ke penyusunan model-model implementasi kebijakan publik. Jakarta: PT Bumi Aksara.

[24]. Edward III, G.C., 1989. Implementing Public Policy (Implementasi Kebijakan Publik). 